\title{
Pakistan's Participation in the War on Terror and US Concerns: An Analysis
}

\begin{abstract}
Ishrat Afshan Abbasi ${ }^{1}$
Abstract

Pakistan was selected as a frontline state in the US-led war against terrorism for two fundamental reasons: at instant, the US wanted to isolate Afghanistan and Taliban breaking its alliance with Pakistan and the second reason was Pakistan's geostrategic position to make this war favorable for US from several perspectives. Whereas for Pakistan this participation was based on a three-pronged strategy: firstly, to avoid the wrath of the US; secondly, to make the best use of this opportunity for economic benefits; and thirdly, to thwart all Indian propagandas to postulate Pakistan as a sponsor of extremism and terrorism. This article explores the backdrop of Pakistan's major interests in the war on terror and the ground realities related to its participation. It also discusses the major concerns of the US regarding Pakistan's performance in this war. In addition, this article addresses the questions about weaknesses and loopholes of this war due to which Pakistan is still entangled in this endless action beyond the decade.
\end{abstract}

Keywords: War on terror, Afghan Taliban, Pakistan, al Qaeda, safe havens, frontline-state, Pakistani Taliban, militancy

\section{Introduction}

On the evening of September 11, 2001, the US administration declared Osama Bin Laden and al Qaeda accountable for the terrorist attacks on twin towers and Pentagon and Afghanistan as the accomplice to the terrorist network because the American Airlines Flight 77, which had crashed into Pentagon was reportedly carrying three al Qaeda operatives. Besides, al Qaeda was threatening US since years for attacks there for it was near certainty that it was only al Qaeda which could organize and act upon its intentions. George Tenet, the CIA chief reported that intelligence service had overheard the greetings of al Qaeda operatives to each other for successful deadly action against the US and they would plan further same level of attacks (Woodward, 2002). Immediately after the attacks the US President George W. Bush, in his address to the nation, made somewhat obvious points in order to countering the future danger which was still looming over the heads of American people. He said, "We have made the decision to punish whoever harbors terrorists, not just the perpetrators" (Danz \& Woodward). President Bush also resolved to use all resources and means from diplomacy to war for the annihilation of terrorist network. He called for all financial support from world community (Bush, 2001).

The US Secretary of State Colin Powell and Deputy Secretary of State Richard Armitage were assigned the duty to isolate the Taliban regime in view of this agenda then focal point was Pakistan because of its close geo-strategic and diplomatic relationship with the Taliban regime (Woodward, 2002). Pakistan's relations with the Taliban started with the USSR's invasion in Afghanistan. In fact, there was no Taliban group at that time, Pakistan supported Mujahideen group, which later on emerged with the name of Taliban. The Mujahideen group included Afghan Mujahideen and Pashtun Tribesmen who got education and training in Pakistani religious schools (madressahs) and received support from Pakistan's Inter-Service

${ }^{1}$ Ishrat Afshan Abbasi is Assistant Professor, Department of International Relations, University of Sindh, Jamshoro, ishrat_ir@yahoo.com

\begin{tabular}{llll|l}
\hline JISR-MSSE & Volume 11 & Number 1 & Jaunary - June 2013 & 99
\end{tabular} 
Intelligence (ISI), therefore, the Taliban group is called the brain child of ISI and its relations to Pakistan date back to the era of Soviet invasion of Afghanistan in the 1980s (Laub, 2013).

After the collapse of the Soviet Union, developing trade links with Central Asian Republics (CARs) had been a desperate desire of successive Pakistani governments. Initially, Pakistan backed Gulbadin Hikmatyar, leader of Hizb-e-Islami in an attempt to bring Pashtuns in power even through power sharing agreement for the sake of opening up trade routes to Central Asia. But, later on when Hikmatyar's extremism divided Pashtuns into factions and Afghan people quit supporting Hikmatyar, it up set Pakistani military and government and they started looking around for the alternate Pashtun proxies (Rashid, 2003). Pakistan recognized the emerging Taliban movement in Afghanistan for various reasons. Winning the confidence of the Taliban Pakistan could reach the energy resources of Central Asia; it could achieve strategic depth against India in Central Asia. Because even with its late access into the Central Asian region, India attempted to make major gains at the expense of Pakistan competing for the immense energy reserves and getting advantage of its geo-strategic significance in its relationship with Russia and China (Akbaryaddeh, 2003).

Besides, Pakistan hoped for the resolution of all bilateral conflicts with Afghanistan, including the matter of Durand Line and Pashtun Nationalism. As According to Ahmed Rashid (2002, pp.185-186):

The Taliban, drawn from the majority of Pashtun ethnic group which accounts for some 40 percent of Afghanistan's 20 million people, had also galvanized Pashtun nationalism. The Pashtun had ruled over Afghanistan for 300 years but recently lost out to the country's other smaller ethnic groups. The Taliban victory revived hopes that once again the Pashtun would dominate Afghanistan.

The emerging Taliban movement attracted Pakistani establishment. It was in October 1994, when Pakistani security officials contacted Mullah Omar (a Taliban leader) in order to seek his help for transporting goods to Turkmenistan. Naseerullah Babar, a retired general and interior minister in Benazir Bhutto's government was impressed with the Taliban's manifesto for peace and stability in the war-ravaged Afghanistan and hoped it would hand out Pakistan's long-standing economic and strategic interests as such (Hussain, 2010).

As oppose to the expectations of Pakistan's military and government, the Taliban regime refused to recognize the Durand Line and withdraw Afghanistan's claims to parts of NWFP. Their decision affected Pakistani Pashtun community as that decision fostered Pashtun nationalism in NWFP. In addition, they started providing sanctuaries and supplying arms to Sunni extremists (Deo Bandi group) in Pakistan against Shittie group. They aimed at Sunni Revolution in Pakistan. In fact, this backward movement was heading to Pakistan with the intention of Talibanization of Pakistan (Rashid, 2002).

Consequently, Pakistan was to face heavy losses owing to smuggling from Afghanistan that was extensively criticized by the international community. Smuggling became the major source of income for the Taliban which undermined the economies of neighboring states. The illegal trade between Pakistan and Afghanistan extended to Central Asian states, Iran and Persian Gulf, and resultantly, Pakistan and all those countries bore heavy losses of revenue and shocks to local industries as local industries' profits were reduced as a result of the smuggling of foreign consumer goods. It was time to revise Pakistan's policy to Afghanistan

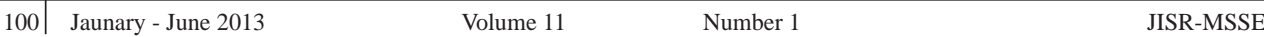


and subdue extremism and political fragmentation on country level. But, in this case the ISI had no second look policy or flexibility to adapt the changing situation by reason of their Kashmir policy, wish for getting advantage against rival India and mainly because of the presence of some extremists in the agencies (Hussain, 2010).

\section{Backdrop of Pakistan's Participation in the War on Terror}

In the wake of 9/11 attacks, Pakistan was warned of the consequences of giving negative response to the US call for joining the war against terrorism (Jones, 2002). In case of support to the US, Pakistan was demanded to hinder the routes of al Qaeda to Pakistan and all support of Osama bin Laden to the radical groups within country, cut off all shipments of fuel to the Taliban and provide harbors to the US aircrafts and territorial access for military and intelligence operations. Pakistan was also asked for sharing intelligence and immigration information and to eradicate all terrorists' expressions in Pakistan against US and its allies (Woodward, 2002).

The then President of Pakistan Pervez Musharraf in his book, In the line of Fire, while analyzing pros and cons of the options he had in case of opposing the US writes that there could be a violent and aggressive reaction against Pakistan . He decided on joining the USled war on three accounts. First of all, they considered Pakistan as a militarily weak country, which could not retaliate any US aggressive action. Secondly, Pakistan is economically weak country, which cannot sustain any economic blockade. The third reason was Pakistan's fragmented society on linguistic, ethnic and sectarian bases (Musharraf, 2008). Analyzing Pakistan's interest in this war, president Musharraf concluded that if Pakistan did not provide bases to the US, India would have been used as an alternative option and it could leverage the case of Kashmir. Moreover, one of the main issues was of security of Pakistan's nuclear weapons; Pakistan was sure about Indian propaganda against its nuclear parity so the time could be appropriate for India to win the support of international community in this respect (Musharraf, 2008).

On the other hand, while explaining benefits of supporting the US, president Musharraf says that by utilizing this opportunity Pakistan could eradicate extremist factors in Pakistan in collaboration with international community with the help of all financial and military support from the US and its allied powers and could support economic infrastructure of the country and boost up its reputation in the international community. In view of all these concerns and decisions, president Musharaf accepted all seven demands. President Musharaf's decision was reported by Collin Powell during the National Security Council meeting and admired by Bush in these words "It looks like you got it all".

On 14 September 2001, president Musharaf called a meeting of corps commanders to inform them about the US demands. He was clear in his decision to support the US unconditionally but many of his senior commanders were upset on this U-turn in Pakistan's Afghan policy and insisted for Washington's cooperation in return for Islamabad's cooperation. But president Musharraf took just six hours to change Pakistan's policy vis-á-vis Afghanistan (Jones, 2002).

The Bush administration was surprised over Musharaf's decision to support the US without any resistance. They were estimating the dangers to Pakistan in case of this support. The US Secretary of State, Condoleeza Rice, and Vice President, Dick Cheney viewed that in case

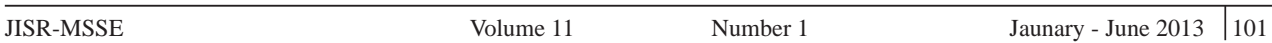


of supporting the US, Pakistan would have allowed running free a whole other set of demons and this decision could annoy the extremists factors for bringing down president Musharaf's government. The decision could give chance to fundamentalists to access and control Pakistan's nuclear weapons. Bush was surprised that had Pakistanis fully thought the risks of supporting the United States:

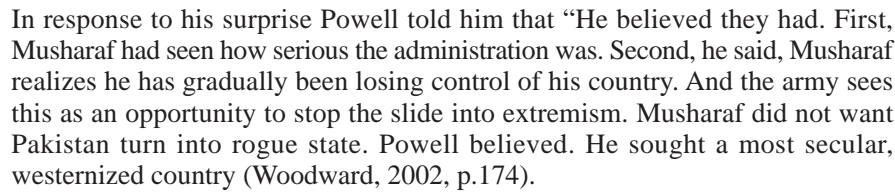
Musharaf had seen how serious the administration was. Second, he said, Musharaf realizes he has gradually been losing control of his country. And the army sees this as an opportunity to stop the slide into extremism. Musharaf did not wan Pakistan turn into rogue state. Powell believed. He sought a most secular, westernized country (Woodward, 2002, p.174)

President Musharaf's choice to support the US in the war on terror brought about immediate financial benefits to Pakistan. Along with Pakistan's balance sheet this decision helped president Musharaf personally raising his international political standing. While president Musharaf pleased the West, at home he had to face severe criticism, demonstrations from extremists in favor of their Afghan brethren. Pakistan's intelligence agency was also divided on this decision (Jones, 2002). In order to win the support of the ISI in his favor, president Musharaf took a dramatic step, dismissing his intelligence chief Gerneral Mahmood, and several of his lieutenants. The US was happy on this decision and Tenet expressed his excitement in these words "the bad witch was dead" (Woodward 2002).

The next task that president Musharaf took up was to curtail al Qaeda operatives and extradite the members them to the US. On September 16, 2001, Government of Pakistan made an effort to turn away the looming likelihood of an attack over Afghanistan by sending a delegation to Afghanistan in order to convince the Taliban to surrender bin Laden to the US, however, the mission failed in its task. It was informed that a delegation member Mufti Shamzai, a renowned religious scholar of Pakistan encouraged Mullah Omar to wage Jihad against the US (Abbas, 2005).

While the US had already laid down a three page "Counter Terror Strategy" that listed the following points:

1. Instruct all tribal allies to ground and identify all their aircraft immediately.

2. Instruct the tribal to cease all significant military movements basically to stand down and hold in place.

3. The future plan was to have the opposition forces drive to isolate enemy forces, but to wait before moving.

4. Instruct all assets throughout Afghanistan to begin sabotage operations immediately everywhere. This would include tossing hand grenades through Taliban offices, disrupting Taliban convoys, pinning down those moving Taliban supplies and ammunition, and generally making pests of them. (This would be the first employment of concerted lethal force in Bush's war on terrorism.

5. Informing all of them that paramilitary insertions would go forward in the south and be combined with more specific air strikes. 
6. All would have to define no strike zones -hospitals, schools.

7. All tribal factions and leaders should identify and locate primary targets.

8. Assets should try to identify possible escape routes out of Afghanistan for bin Laden and his al Qadea leadership and then try to set up reconnaissance of the routes for interdiction.

9. Be prepared to interrogate and exploit prisoners.

10. Assess humanitarian needs

11. They were instructed to share the full text with General Franks to make sure of complete transparency with the military commander (Woodward, 2002).

On October 7, 2001, the US attack on Afghanistan helped Pakistan to finalize and consolidate its decision for U-turn in its internal and external policy. At external level Pakistan abandoned all relations with Afghanistan and provided full support to the US in its military campaign while internally president Musharaf altered the old tradition of the military government of Pakistan to support hard-liner religious groups, inversely he took measures against them (Sattar, 2007).

In November 2001, government released 200 religious extremists and militants with this understanding that this policy will help government to get rid of some notorious and extremist militants who will refrain from participation in any terrorist campaign in future but the estimation went wrong when a few of them found guilty of the two assassination attempts on president Mushararaf in December 2003 (Hussain, 2007).

\section{Pakistan's Participation in the War on Terror: US Concerns}

Although Pakistan participated as a frontline state in the war on terror, initially this decision was taken by General Musharaf in view of some national and personal interests these included: deep fear about turning away of the situation in favor of India, stability of Pakistan's nuclear program, freedom from bias and favoritism in case of Kashmir, to avoid being target of attack in the US-led war on terror and to hold on its grip over dictatorial rule (Tellis, 2002). However, Musharaf was reluctant to cut ties with the Taliban, which were nurtured, trained and supported by Islamabad in view of its Central Asia general and Afghanistan specific policy. Islamabad's strong affiliation with the Taliban was witnessed during Operation Enduring Freedom when president Musharaf and his cohort tried to defend Mullah Omar's regime in Afghanistan offering mediatory role to avoid the expected attack against Afghanistan (Sattar, 2007).

By reason of joint US-Northern Alliance military operations many al Qaeda operatives infiltrated porous Afghan-Pakistan border and took refuge in Pakistan's Federally Administered Tribal Areas (FATA). However, some operatives were seized at border areas but the quality of operators was not satisfactory and vigorous enough by reason of other factors like, the tribal were extending relief and aid to their guests in line with their tradition by reasons of their ethnical and linguistic and affinity, for their connection with Jihadi culture, for their war against Northern Alliance, and for having very weak Pakistani writ in the area, and complicated topography with mountains pieces of land and poor communication system, all these factors made FATA a safe haven for militants.

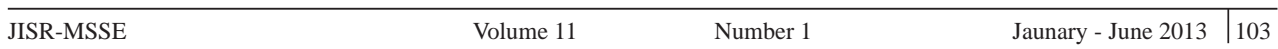


Pakistan was compelled to be active in this war on terror, in this regard; president Musharaf was required to expose the sources of terrorism nurtured internally in Pakistan and combat against them. The US believed that most of the sources of terrorism in Pakistan like radical Islamic movements were developed and patronized by its own military organization's campaign and Intelligence to secure and promote Pakistan's interest in Kashmir and Afghanistan (Tellis, 2002).

President Mushrraf's initial steps against terrorist groups were against sectarian religious organizations, including Deobandi and Shia groups such as, Lashkar-e-Jhangvi, Sipah-eSahaba Pakistan and its members Lashkar-e-Jhangvi \& Shia Therik-e-Jafria Pakistan and its descendants Sipah-e-Muhammadi which were involved in bloodshed within territory. Thereby, it can be said that exploiting war on terror was a source to dismantle only selective groups which were a challenge to country's national interest and engaged in sectarian violence within the country.

The groups such as Lashkar-e-Taiba, Jaish-e-Muhammad and Harkatul-Mujahideen were treated differently for being groups that worked as a team with military and ISI units in their anti- India policies in Kashmir. These groups were financially supported and trained by the Pakistan army. After December 13, 2001 attacks on the Indian parliament, the US compelled Pakistan to take appropriate measures against the groups too and pull them up by the roots. So far as Taliban groups were concerned, it is target was also avoided by president Musharraf initially yet (Tellis, 2002).

In addition, the senior military officials had their own reservations about the Taliban for various reasons. First of all, Taliban are Ghazali Pashtun who had very profound linkages with the tribes of the FATA. Pakistan military was afraid of targeting the Taliban presence in the FATA for any kind of furtherance of aggression at tribal level and deterioration of relations among military and tribal leaders. Second cause was liaison relationship between the ISI and the Taliban over the years. Thus Pakistan's failure to target the Taliban had created several consequences for Afghanistan and the US. These included: (i) Horrible attacks in the West, particularly the US; (ii) it gave a free hand to the Taliban to cultivate their native bases of support within Southern and Eastern Afghanistan; (iii) the emergence of another Islamic militant group called Pakistani Taliban, sympathetic and committed to al Qaeda in its ideology and plans and responsible for undermining government of Pakistan's writ in the FATA particularly and all over country generally, as well as waging a holy war against liberal elements within Pakistan (Tellis, 2002).

\section{Analysis of Pakistan's Participation in the War on Terror}

In reality, the Government of Pakistan was unwilling to completely eradicate jihadis. The obstacle in the way of complete and effective crack down on jihadi group was Government's Kashmir Policy. These jihadi's were a great source of Pakistan to keep on its war against Indian military in Kashmir (Abbas, 2005). 
However, under the US pressure Musharaf launched crack down on the militants. In this campaign leading al Qaeda members like Abu Zubaida and Khalid Sheikh Mohammad were arrested and hundreds of them were handed over to the US. In appreciation to this efficiency the US awarded a 3 billion dollars aid package to Pakistan for over five years period. But, the half of the aid was to be disbursed for armed forces and defense procurements. However, internationally Musharaf got recognition as a hero of US war on terror yet domestically hefaced staunch resistance and rebellion especially in the tribal areas (Abbas, 2005). Pakistan's decision to join the US-led war on terror as a frontline state has many questions and loopholes. First at that time the country was ruled by military regime under one-man show. Second, Parliament was not taken into confidence in its any decision. Third the decision has had no popular support. Fourth, in the words of the US Secretary of State, Colin Powell, Musharaf accepted all seven demands of US because he has been losing control of his country. Similarly, in the subsequent in a press conference Pervez Musaraf confessed that he used the war on terror to perpetuate his rule in order to save the country from devastation and going back to the stone age, but today, the long and protracted war on terror gives an impression that still Pakistan is engaged in the struggle to save itself from the destruction. As a result of war what catastrophes are faced they range from civil war to suicide bombing and tattered economy to psychological tensions.

It seems even after a decade Pakistan has not achieved its goals. Saving Pakistan from US bombardment, Pakistan has lost many lives in carpet bombings, military operations; US drone attacks, suicide attacks, and other same kind of terrorism related incidents during that time. Despite this still Pakistan is unable to have the position of trusted ally in the eyes of the US administration.

\section{Conclusion}

When Pakistan joined the US in its war on terrorism, the country was considered to be a hub of foreign jihadis who were fighting Pakistan's war in Kashmir, Iran and other areas. Despite that Pakistan's then chief executive decided to join US-led war for eradicating extremism and terrorism in Pakistan and preventing cross-border terrorism. It was quite amazing and unbelievable decision, but according to Pervez Musharaf, the decision was taken in view of some national and international demands including Pakistan's socio economic condition, pressure from International community in general and US in particular, and struggle against Indian propagandas. Regardless of president Musharaf's rational statement the current scenario on this matter of war on terror verifies some US concerns regarding Pakistan's double stand on this matter as with time frontier areas of Pakistan became strong hubs for foreign militants and the number of militants was increasing rather than being decreased for the sympathy of local people for these militant figures. Moreover, US was concerned about ISI and military patronization of these jihadi groups; besides it was visible that mostly the targeted groups were anti-jihadi violence groups; whereas US believed that most of the sources of terrorism in Pakistan like radical Islamic movements were developed and patronized by its own military organization's campaign and Intelligence to secure and promote Pakistan's interest and adventures in Kashmir and Afghanistan.

Thereby, it can be said that exploiting war on terror was a source to dismantle selectively those groups which were a challenge to country's national interest and engaged in antinational jihadi violence within country while the cross border attacks against US and NATO

\begin{tabular}{llll|l}
\hline JISR-MSSE & Volume 11 & Number 1 & Jaunary - June 2013 & 105
\end{tabular} 
(North Atlantic Treaty Organization) forces were still continue. Even as, all the demanded al Qaeda and the Taliban figures were mostly killed through drone attacks by US agencies not Pakistani military forces or agencies. These bitter realities always pushed US to demand more and more from Pakistani government. For Pakistan, Pakistani public has been waiting for long to witness windup of this war on terror but this war has been decade long due to its loopholes; amongst them the simplest reason is lack of coordination in the polices of government, military and security agencies on the interest, strategy and plans on war against terrorism.

\section{References}

Abbas, H. (2005). Pakistan's Drift into Extremism: Allah, the Army and America's War on Terror. New Delhi: Pentagon Press.

Akbaryaddeh, S. (2003). India and Pakistan's Geo-Strategic Rivalry in Central Asia. Contemporary South Asia, 12(2), 219-228.

Balz, D., \& Woodward, B. (2002, January 27). America's Chaotic Road to War. Washington Post.

Hussain, Z. (2010). Front Line Pakistan: The Path to Catastrophe and the Killing of Benazir Bhutto. London: I.B.Tauris.

Hussain, Z. (2007). Frontline Pakistan the Struggle with Militant Islam. Islamabad: Vanguard Books (Pvt.) Ltd.

Jones, O. B. (2002). Pakistan: Eye of the Storm. New Haven, CT: Yale University Press.

Laub, Z. (2013). The Taliban in Afghanistan. Council on Foreign Relations. Also available at http://www.cfr.org/afghanistan/taliban-afghanistan/p105510

Musharaf, P. (2008). In the Line of Fire. London: Simon \& Schuster.

Rashid, A. (2000). Taliban: Islam, oil and the new Great Game in Central Asia. London: I.B.Tauris.

Sattar, A. (2007). Pakistan's Foreign Policy 1947-2005 A Concise History. Karachi: Oxford University Press.

Speech of President George W. Bush (2001). Retrieved from http://www.historyplace.com

Tellis, A. J. (2002). Pakistan and the War on Terror: Conflicted Goals Compromised Performance. Carnegie Endowment: Washington D.C.

Woodward, B. (2002). Bush at War. New York: Simon \& Schuster.

\begin{tabular}{l|llll}
\hline 106 & Jaunary - June 2013 & Volume 11 & Number 1 & JISR-MSSE
\end{tabular} 